\title{
Congenital Prepubic Sinus (Type 2 Stephens Variant of Epispadiac Dorsal Urethral Duplication): An Uncommon Anomaly
}

\author{
Sumit Dhuria* and William Bhatti \\ Department of Paediatric surgery, Christian medical college \& Hospital, India
}

Submission: November 19, 2016; Published: February 17, 2017

*Corresponding author: Sumit Dhuria, Department of Paediatric surgery, Christian medical college \& Hospital, Ludhiana, Punjab, India, 141001, Email: Dr_sumitdhuria@yahoo.co.in

\begin{abstract}
Variants of congenital prepubic sinus have been reported rarely, and because the anatomic features often differ from each other, a consensus concerning the embryology and classification was not achieved yet. Various names including congenital prepubic sinus, sub pubic fistula, prepubic dermoid sinus, and suprapubic dermoid sinus, were used to identify these lesions, and, among the classifications available, none seems to clearly describe this entity. We present a 2-year old boy with a case of epispadiac variant of urethral duplication in which the duplicated urethra presented as a prepubic sinus. We report this uncommon anomaly and review the scattered published reports to improve the global understanding of this uncommon congenital lesion.
\end{abstract}

Keywords: Urethral duplication; Epispadias; Congenital prepubic sinus; Sinus tract

\section{Introduction}

Congenital prepubic sinus (CPS) is a rare anomaly of uncertain etiology. The sinus usually presents as a small tract, commencing on the skin overlying the penis or prepubic area, and extending toward the anterior bladder wall or umbilicus $[1,2]$. The anatomic and pathologic features of this disorder have been documented, but controversies over its embryologic basis are ongoing.

\section{Case Report}

A 2-year-old male child was presented with congenital opening over the dorsal surface of the penis. He was asymptomatic except for occasional clear discharge from the opening. Child was passing urine through the normal urethral opening. Local examination revealed a deformed penis with ventrally hooded prepuce and $8 \mathrm{~mm}$ midline epispadiac opening over the dorsal surface of the penis. A number 8 infant feeding tube could be easily passed in the opening for a distance of $3 \mathrm{~cm}$ and could be felt going under the pubic symphysis (Figure 1a \& 1b). Fistulography was showing blind ending tract around $2.5 \mathrm{~cm}$ long going up towards the prevesical space without any communication with bladder (Figure 2a \& 2b). At operation, the tract was dissected and was found to be going under the pubic symphysis (Figure $3 a$ \& $3 b$ ). The tract was traced up to prevesical space, transfixed, ligated and divided. Specimen $(2.5 \mathrm{~cm}$ sinus tract) was sent for histopathology which showed tract lined by transitional epithelium and focal inflammation (Figure 4).

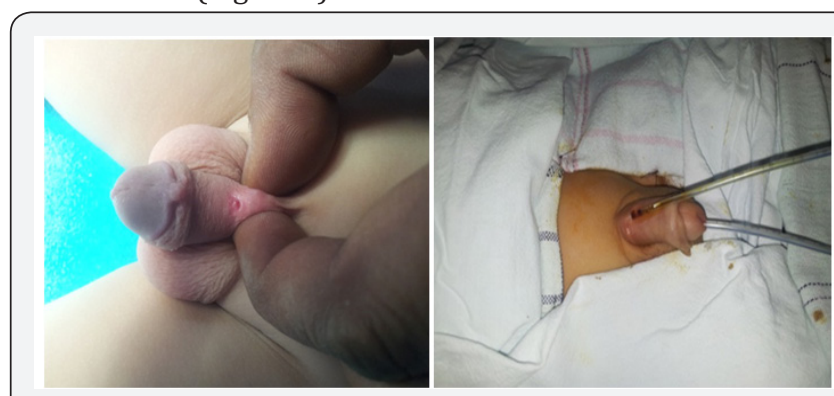

Figure 1 a \& b: Sinus opening over the prepubic area and a ventrally hooded prepuce.

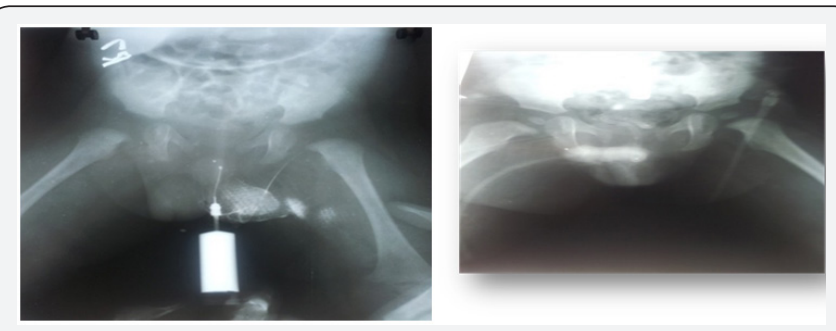

Figure 2 a \& b: Fistulography showing tract ending blindly without any communication with bladder. 


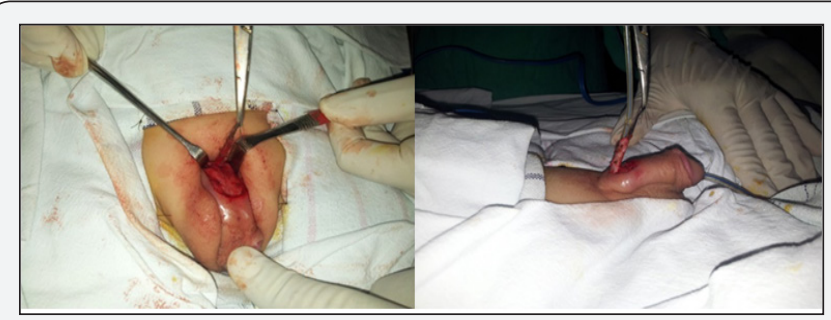

Figure 3 a \& b: Intraoperative findings of sinus tract.

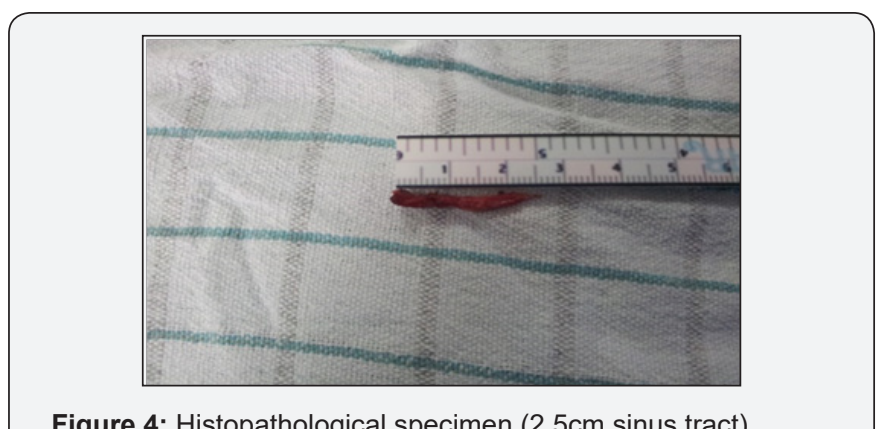

Figure 4: Histopathological specimen $(2.5 \mathrm{~cm}$ sinus tract).

\section{Discussion}

Congenital prepubic sinus is a tract originating in the skin overlying the symphysis pubis, superior to the base of the penis or clitoris, and extending to, but not communicating with, the anterior bladder wall [3]. There are four generally proposed theories for the etiology of Congenital prepubic sinus: First anomaly of abdominal wall closure [4]; and second urethral developmental anomaly, a variant of dorsal urethral duplication [1,2,5-8]. The third theory is that it is a congenital fistula of the primitive urogenital sinus, with three anatomic subtypes depending on the direction of the sinus tract: high, toward the urachal remnant; middle, toward the bladder; and low, toward the prostatic urethra [9]. Fourth theory suggests that it is a remnant of the cloaca [10]. Of all these theories, reports supporting the anomaly of dorsal urethral duplication predominate $[1,3,5-8,11]$. As these theories cannot explain all the varied presentations of CPS, Tsukamoto et al. postulated recently that CPS may be caused by a residual cloaca membrane and umbilicophallic groove, and that the depth may determine the position of the end of the sinus tract [12]. However, Huang et al. [1] used an immunohistochemical staining technique of the excised sinus to reinforce the theory of dorsal urethral duplication in a report of five patients with congenital prepubic sinus, when they found the presence of transitional epithelium in the proximal part of the sinus with surrounding smooth muscle bundles [1]. Balster et al. [11] in 2003 also supported this assumption with an immunohistochemical study on the excised sinus tract of a 2-year-old boy with a skin fistula on the dorsal side of the penis [11]. Urethral duplication remains a rare and confusing problem, more so when it presents as a prepubic sinus. Urethral duplication does not represent a uniform entity making it difficult to find an unequivocal and comprehensive classification. Stephens described three types of dorsal urethral duplication according to the anatomy [13]. Type 1 is a complete or incomplete channel that runs parallel to the normal urethra from the glans to the bladder, which may join the urethra or ends blindly. Type 2 is an epispadiac type of channel from the dorsum of the penis to the bladder or one that joins the urethra at some point. Type 3 is a dermoid sinus that simulates an accessory urethra but tracks from the base of the penis in front of the pelvic urethra and bladder behind the pubic symphysis to or towards the umbilicus. We found only 7 reports of 9 cases of epispadiac variant of dorsal urethral duplication in the English literature (Table 1) (6,8,14-18). The similarity of the anatomy of our case to the type 2 variant of the Stephens classification favours the theory that Congenital prepubic sinus is a variant of dorsal urethral duplication. The presence of transitional epithelium in the lining of the sinus in this patient reinforced this theory. Although the tract ended blindly toward the anterior bladder wall, the presence of dorsal chordee, a ventrally hooded prepuce as well as penile torsion supports an epispadiac variant.

Table 1: Published cases of congenital prepubic sinus with epispadiac variant of dorsal urethral duplication.

\begin{tabular}{|c|c|c|c|}
\hline Studies & Number of Patients/ Sex & Histopathology & Diagnosis \\
\hline Campbell et al. [6] & 1M, 2F & $\begin{array}{c}\text { Proximal transitional; distal squamous surrounded } \\
\text { by smooth muscle in 2; stratified squamous in 1 }\end{array}$ & $\begin{array}{c}\text { Variant of epispadiac duplication } \\
\text { of the urethra (Stephens type 2) }\end{array}$ \\
\hline Gonzalez et al. [14] & 1M & Stratified squamous surrounded by smooth muscle & $\begin{array}{c}\text { Variant of dorsal urethral } \\
\text { duplication (intermediate } \\
\text { between Stephens type 2 and 3) }\end{array}$ \\
\hline Mostin et al. [17] & $1 \mathrm{M}$ & Proximal transitional; distal Squamous epithelium & $\begin{array}{c}\text { Epispadiac duplication of the } \\
\text { urethra }\end{array}$ \\
\hline $\begin{array}{c}\text { Lopez Aramburu et al. } \\
\text { [15] }\end{array}$ & $1 \mathrm{M}$ & $\begin{array}{c}\text { Proximal transitional; distal squamous, surrounded } \\
\text { by smooth muscle }\end{array}$ & $\begin{array}{c}\text { Variant of epispadiac duplication } \\
\text { of the urethra (Stephens type 2) }\end{array}$ \\
\hline Green et al. [8] & $1 \mathrm{~F}$ & Stratified squamous epithelium & $\begin{array}{c}\text { Variant of epispadiac duplication } \\
\text { of the urethra (Stephens type 2) }\end{array}$ \\
\hline Al-Wattar et al. [16] & $1 \mathrm{M}$ & $\begin{array}{c}\text { Proximal transitional; distal Squamous epithelium, } \\
\text { surrounded by smooth muscle }\end{array}$ & $\begin{array}{c}\text { Variant of epispadiac duplication } \\
\text { of the urethra (Stephens type 2) }\end{array}$ \\
\hline
\end{tabular}




\section{Academic Journal of Pediatrics \& Neonatology}

\begin{tabular}{|c|c|c|c|}
\hline $\begin{array}{c}\text { Abdulrasheed A. Nasir } \\
\text { et al. [18] }\end{array}$ & 1M & Transitional epithelium & $\begin{array}{c}\text { Variant of epispadiac duplication } \\
\text { of the urethra (Stephens type2) }\end{array}$ \\
\hline Current case & $1 \mathrm{M}$ & Tract lined by transitional epithelium and focal & $\begin{array}{c}\text { Variant of epispadiac duplication } \\
\text { of the urethra (Stephens type2) }\end{array}$ \\
\hline
\end{tabular}

Patient with Congenital prepubic sinus should be thoroughly evaluated because of its variable presentation, come to medical attention because of the opening or because of persistent discharge. Diagnosis is mainly clinical but imaging techniques such as micturating cystourethrogram and sinogram could help to outline the direction of the tract, and whether it is blind ending or communicating with the urinary tract. Treatment is individualized depending on the anatomy and severity of the anomaly, and usually consists of excision of the non dominant urethra or sinus tract, usually the dorsal one. Excision is usually curative.

\section{References}

1. Huang CC, Wu WH, Chai CY, Chuang JH (2001) Congenital prepubic sinus: a variant of dorsal urethral duplication suggested by immunohistochemical analysis. J Urol 166(5): 1876-1879.

2. Ozdemir E, Yildiz T, Kanbay M, Kanbay S (2011) A case of congenital prepubic sinus. Eur J Pediatr Surg 21(6): 408-409.

3. Usami M, Hayashi Y, Kojima Y, Maruyama T, Tozawa K, et al. (2005) Congenital prepubic sinus: a variant of urethral duplication (Stephens type 3). Int J Urol 12 (2): 231-233.

4. Komura J, Yano H, Kanazawa M, Tanaka Y, Takagishi T, et al. (1994) Congenital prepubic sinus. Paediatr Surg Int 9(4): 287-289.

5. Kim HY, Shin OR, Jang ED, Yoon B, Chung MS, et al. (2007) Congenital prepubic sinus: a variant of urethral duplication. Korean J Urol 48: 881884

6. Campbell J, Beasley S, McMullin N, Hutson JM (1987) Congenital prepubic sinus: possible variant of dorsal urethral duplication (Stephens type 2). J Urol 137(3): 505-506.

7. Chao HM, Chuang CJ, Chen KC, Chu CC, Chou JM (2002) Unusual epithelium in a subpubic sinus. Pediatr Surg Int 18(5-6): 494-495.
8. Green JS, Madden NP (1997) Congenital prepubic sinus: a form of dorsal duplication. Br J Urol 80(6): 964

9. Soares-Oliveira M, Julia V, Aparicio G, Morales L (2002) Congenital prepubic sinus. J Pediatr Surg 37(8): 1225-1227.

10. Chou TD, Chu CC, Diau GY, Chiang JH (1995) Subpubic sinus: a remnant of cloaca. J Urol 153(5): 1671-1672.

11. Balster S, Bettendorf O, Brinkmann OA, Hertle L (2003) Congenital prepubic sinus: etiology and therapy. Aktuelle Urol 34(7): 484-487.

12. Tsukamoto K, Yamataka A, Kuga T, Yanai T, Watanabe T, et al. (2004) Congenital prepubic sinus: is it a residual cloacal membrane and umbilicophallic groove? Pediatr Surg Int 20(1): 47-50.

13. Stephens FD (1983) Abnormal embryology-cloacal dysgenesis. In: Congenital malformations of the urinary tract. Praeger Scientific, New York, p. 22.

14. Gonzalez J, Marco A, Andujar M (1993) Congenital prepubic sinus: blind epispadial duplication of the urethral. Actas Urol Esp 17(2): 153156.

15. Lopez Aramburu MA, Gutierrez Duenas JM, Martin Melero MD, Arroyo Munoz JL, Rosa Arias J (1996) Congenital prepubic sinus. Actas Urol Esp 20(2): 172-174.

16. Al-Wattar KM (2003) Congenital prepubic sinus: an epispadiac variant of urethral duplication: case report and review of literature. J Pediatr Surg 38(4): E10.

17. Mostin J, Tombal B, Keupens F, Opsomer R, Clapuyt P, et al. (1995) Epispadiac duplication of the urethral. Acta Urol Belg 63(1): 37-42.

18. Nasir AA, Abdur-Rahman LO, Olaoye I, Oyinloye AO, Bamigbola KT, et al. (2013) Congenital prepubic sinus: A variant of epispadiac dorsal urethral duplication. Journal of Pediatric Urology 9(1): e82-e85.

\begin{tabular}{l} 
Your next submission with Juniper Publishers \\
will reach you the below assets \\
- Quality Editorial service \\
- Swift Peer Review \\
- Reprints availability \\
- E-prints Service \\
- Manuscript Podcast for convenient understanding \\
- Global attainment for your research \\
- Manuscript accessibility in different formats \\
( Pdf, E-pub, Full Text, Audio) \\
- Unceasing customer service \\
Track the below URL for one-step submission \\
https://juniperpublishers.com/online-submission.php \\
\hline
\end{tabular}

